\title{
ISOLATION, PURIFICATION AND CHARACTERISATION OF TRANSGLUTAMINASE FROM ROSEMARY (ROSMARINUS OFFICINALIS L.) LEAVES
}

\author{
Mahmoud El-Hofi ${ }^{1 凶}$, Azza Ismail ${ }^{1}$, Maher Nour $^{2}$, Osama Ibrahim ${ }^{1}$ \\ ${ }^{1}$ Dairy Sciences Department, National Research Centre in Dokki, Cairo, Egypt \\ 2Dairy Science Department, Azhar University, Cairo, Egypt
}

\begin{abstract}
Background. Rosemary (Rosmarinus officinalis L.) is a spice and medicinal herb widely used around the world of the natural antioxidants, and it has been widely accepted as one of the spices with the highest antioxidant activity. Transglutaminase (EC 2.3.2.13; TGase) is an enzyme capable of catalysing acyl transfer reactions by introducing covalent cross-links between proteins, as well as peptides and various primary amines. TGase activity in plants was first observed in pea seedlings, and subsequently found in organs of both lower and higher plants. Recently, TGase has captured researchers' interest due to its attractive potential application in food industries. Therefore, the objectives of this study are isolation and purification of TGase from new plant source rosemary (Rosmarinus officinalis L.) leaves at the laboratory scale. Moreover, investigation of the biochemical properties of the purified TGase to provide a suitable TGase enzyme for food industry applications are in focus.

Material and methods. Rosemary (Rosmarinus officinalis L.) leaves was used as a new plant source to TGase. The biochemical characteristics of the crude and purified enzyme were determined.

Results. Rosemary (Rosmarinus officinalis L.) TGase was purified to homogeneity by successive three purification steps including ammonium sulfate precipitatation, ion exchange chromatography on DEAE-Sephadex A-50 column and Size exclusion column chromatography on Sephadex G-100 column. Under experimental conditions, $20-30 \%$ of ammonium sulfate saturation in the enzyme solution had a high yield of enzyme activity could be obtained. The purified enzyme from the Sephadex G-100 column had $21.35 \%$ yield with increased about 7.31 in purification fold. Rosemary TGase exhibited optimum activity at $\mathrm{pH} 7.0$ and $55^{\circ} \mathrm{C}$ for the catalytic reaction of hydroxylamine and Z-Gln-Gly. The purified TGase almost maintained full activity after incubation for $15 \mathrm{~min}$ up to $60^{\circ} \mathrm{C}$ and it was completely inactivated at $85^{\circ} \mathrm{C}$. The rosemary TGase was stimulated at 2-6 $\mathrm{mM} \mathrm{CaCl}_{2}$ concentrations while it lost about $5-20 \%$ from its activity by increasing $\mathrm{CaCl}_{2}$ concentration. Sodium chloride (2-14\%) shows no noticeable inhibition of the purified TGase activity. $\mathrm{Mg}^{+2}$, $\mathrm{Ba}^{+2}$ were acivited by the purified TGase while it was strongly inhibited by $\mathrm{Fe}^{+2}$, moderately by $\mathrm{Cu}^{+2}$ and $\mathrm{Mn}^{+2}$. Conclusion. This paper reports on the purification and characterisation of TGase from newly isolated plant, rosemary (Rosmarinus officinalis L.) leaves. Finding results of the TGase properties make this enzyme a good candidate for application in the food industry. However, additional work is required to increase activity yield during extraction and purification for commercial scale of TGase from this plant.
\end{abstract}

Key words: transglutaminase, purification, rosemary (Rosmarinus officinalis L.), cross-linking

mahmoudhofi@yahoo.com 


\section{INTRODUCTION}

There is an increasing interest in phytochemicals as new sources of natural antioxidant and antimicrobial agents [Tawaha et al. 2007]. Rosemary (Rosmarinus officinalis L.) is a spice and medicinal herb widely used around the world of the natural antioxidants, it has been widely accepted as one of the spices with the highest antioxidant activity [Genena et al. 2008]. Rosemary essential oil is also used as an antibacterial, antifungal [Oluwatuyi et al. 2004, Fernández-López et al. 2005] and anticancer agent [Leal et al. 2003].

Transglutaminase (EC 2.3.2.13; protein glutamine $\gamma$-glutamyl-transferase; TGase) is an enzyme capable of catalysing acyl transfer reactions by introducing covalent cross-links between proteins, as well as peptides and various primary amines. TGase catalyses the crosslinking of proteins through an acyl transfer reaction using the $\gamma$-carboxamide group of peptide-bound glutamine residues as acyl donor and the $\varepsilon$-amino groups of lysine residues as acyl acceptor (Fig. 1) [Folk 1980, Aeschlimann and Paulsson 1994, Zhu et al. 1995].

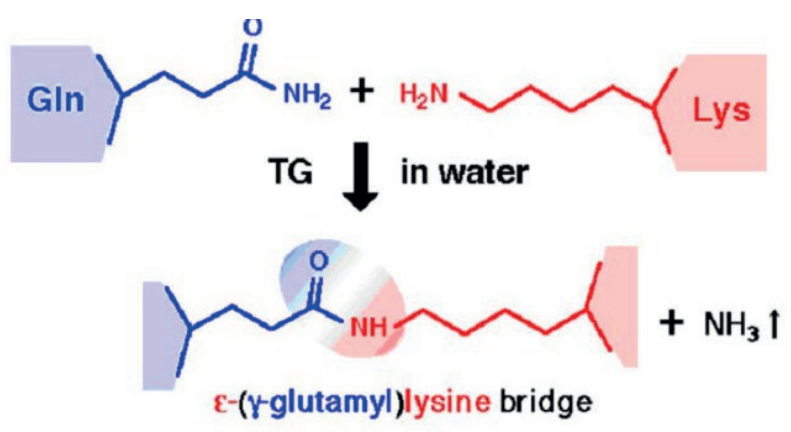

Fig. 1. Reaction mechanism of transglutaminase (TGase; http://www.bioeng.cstm.kyushu-u.ac.jp/enzyme/Transglutamiase1.html)

TGases are widely distributed in many tissues and body fluids of vertebrates. TGase was first discovered in guinea pig liver and characterised by Waelsch and coworkers [Clarke et al. 1959], and identified as an enzyme catalysing incorporation of polyamines into glutamine residues of proteins or peptides [Wilhelm et al. 1996]. In prokaryotes, TGase activity has been found in actinomycetes from the genus Streptoverticillium such as Streptoverticillium S-8112 a variant of Streptoverticillium mobaraense [Ando et al. 1989, Kanaji et al. 1993].

TGase activity in plants was first observed in pea seedlings [Icekson and Apelbaum 1987], and subsequently found in organs of both lower and higher plants. Signorini et al. [1991] identified TGase activity in the leaves of silver beet (Beta vulgaris L.). Kang and Cho [1996] purified TGase from soybean (Glycine max) leaves and Lilley et al. [1998] showed that tissue TGase was also present in pea, broad bean, wheat and barley. Villalobos et al. [2001] identified a maize chloroplast TGase.

TGase is widely used in the cross-linking of most food proteins, such as caseins, soybean, gluten, myosins, actin, and whey proteins [Lin et al. 2007]. Cross-linking reaction can be used to improve functional properties of some food products such as dairy products, meat products and cereal products [Mirzaei 2011]. The functional properties of milk proteins determine many physicochemical properties of dairy products, such as the texture of cheese, the viscosity of yoghurt or the stability of milk to heat treatment. The introduction of additional covalent cross-links by TGase represents a promising tool to improve functional properties such as solubility, water-binding or emulsifying capacity, foaming, viscosity, elasticity and gelation properties of proteins intended for human consumption, where chemical reagents for modification are not acceptable [Li-Chan 2004].

It could be considered that most applications were carried out with guinea pig liver transglutaminase [Gerber et al. 1994]. Recently, TGase has captured researchers' interest due to its attractive potential application in food industries [Zhu et al. 1995], immobilization of enzymes [Josten et al. 1999] and textile industries [Cortez et al. 2004]. The relatively small quantity obtained, complex separation and purification procedure required for TGase from animal tissues. Also, insufficient stability during it is purification led to search for new TGase sources.

Therefore, the objectives of this study are isolation and purification of TGase from new plant source rosemary (Rosmarinus officinalis L.) leaves (Fig. $2 \mathrm{a}, \mathrm{b}$ ) at the laboratory scale. Also, investigate the biochemical properties of the purified TGase to provide a suitable TGase enzyme for food industry applications. 


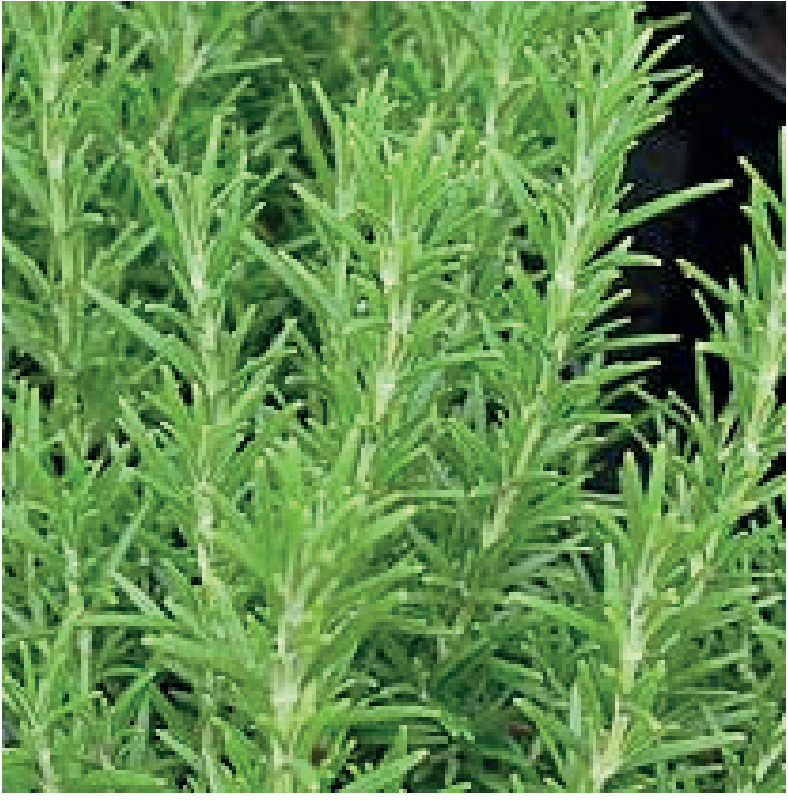

a

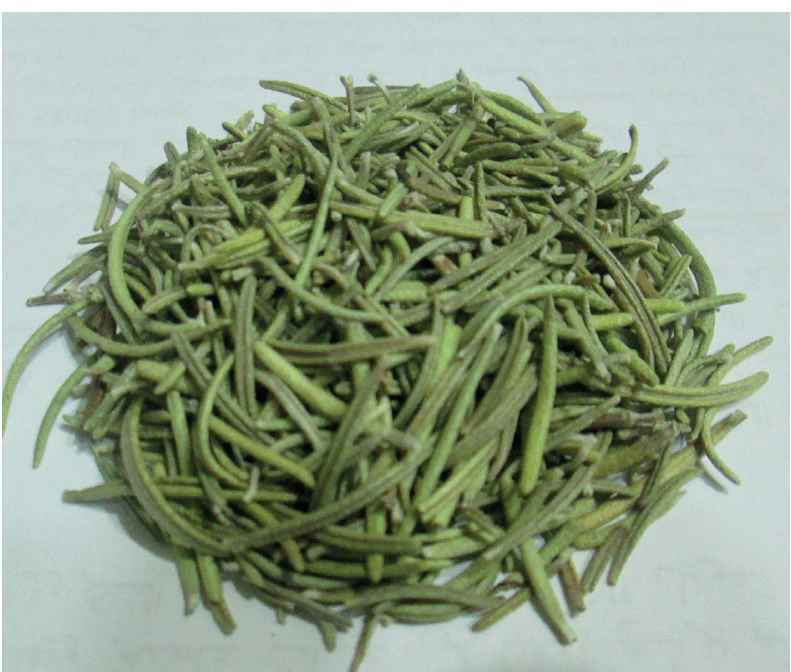

b

Fig. 2. Rosemary plant (Rosmarinus officinalis L.): a - fresh leaves, $\mathrm{b}$ - dried leaves

\section{MATERIAL AND METHODS}

\section{Chemicals}

N-Carbobenzoxy-L-Glutaminylglycine (Z-Gln-Gly); L-Glutamic acid $\gamma$-monohydroxamate; Glutathione, reduced form; Hydroxylamine hydrochloride; Se- phadex G-100, Polyvinylpyrrolidone (PVP) and $\beta$-mercaptoethanol (BME) were purchased from Sigma-Aldrich, Chemical Co., Inc., Germany. DEAE-Sephadex A-50 was purchased from Fluka BioChemica (Buchs, Switzerland). Bovine serum albumin (BSA) was purchased from Mallinckrodf Chemical Co., Inc, France. Dye Coomassie brilliant blue G-250 was purchased from Bio-Rad (Richmond, Calif., USA). All other reagents and chemicals were used of analytical grade.

\section{Buffers}

All buffers used in the $\mathrm{pH}$ measurements were prepared according to Gomori [1955]. Moreover, final pH was checked using $\mathrm{pH}$-meter with glass electrodes, Ingold, Knick, Germany.

\section{Raw material}

Rosemary (Rosmarinus officinalis L.) was obtained from production and marketing of medicinal plants and their extracts unit, Medicinal and Aromatic Plants Research Department, National Research Centre.

\section{Preparation of crude enzyme}

Crude enzyme extract prepared by soaking 50 gram of rosemary leaves in extraction buffer $0.2 \mathrm{M}$ Tris- $\mathrm{HCl}$ buffer $\mathrm{pH} 7.4$ containing, (10 mM EDTA, $25 \mathrm{mM} \mathrm{Su}-$ crose, $0.05 \%$ BME and 3\% PVP) for $24 \mathrm{~h}$, then homogenized in the same buffer using a blender for 1 to 2 minutes. The homogenate was filtered through a four layers of muslin to remove suspended solid particle, and the $\mathrm{pH}$ was readjusted to $7.4 \mathrm{using}$ solid tris. The extract was centrifuged at $5000 \mathrm{rpm}$ for $20 \mathrm{~min}$ at $4{ }^{\circ} \mathrm{C}$. The supernatant was collected and kept for further analysis. The supernatant obtained was called as crude enzyme extract. TGase activity and the protein content were determined.

\section{Purification of rosemary TGase}

Ammonium sulfate precipitation. The crude enzyme was precipitated by the addition of solid $\left(\mathrm{NH}_{4}\right)_{2} \mathrm{SO}_{4}$ to $90 \%$ saturation according to Colowick and Kaplan [1955]. The sedimentary protein was collected by centrifugation at $5000 \mathrm{rpm}$ for $15 \mathrm{~min}$ at $4^{\circ} \mathrm{C}$. The supernatant is discarded. The precipitate is redissolved in a minimum quantity of $20 \mathrm{mM}$ Tris- $\mathrm{HCl}$ buffer $\mathrm{pH} 7.4(10 \mathrm{ml})$. The highly active fraction was 
dialysed against a large volume of the same buffer overnight.

\section{Ion Exchange Chromatography on DEAE-Sephad- ex A-50}

The dialysed fraction is applied onto a DEAE-Sephadex A-50 column $(1.5 \times 25 \mathrm{~cm})$ equilibrated with $20 \mathrm{mM}$ Tris- $\mathrm{HCl}$ buffer $\mathrm{pH}$ (7.4). After the sample application, the column was washed with the same buffer to remove unbound proteins. The protein fraction bound to the matrix (including the target protein) is eluted with a linear 0 to $0.5 \mathrm{M} \mathrm{NaCl}$ gradient, prepared in the same buffer at a flow rate of $1.0 \mathrm{ml} / \mathrm{min}$. Fractions $(10 \mathrm{ml})$ were collected and their protein absorbance at $280 \mathrm{~nm}$ was recorded and the TGase activity was assayed. Fractions with TGase activity were pooled and dialysed overnight against $20 \mathrm{mM}$ Tris- $\mathrm{HCl}$ buffer $\mathrm{pH}$ 7.4.

\section{Size exclusion column chromatography on Sephadex G-100}

The dialysed fractions were further purified by applied on Sephadex G-100 column $(2.5 \times 37 \mathrm{~cm})$ (Phamacia, Uppsala, Sweden), equilibrated with $20 \mathrm{mM}$ Tris- $\mathrm{HCl}$ buffer $\mathrm{pH}$ (7.4) and the sample eluted with the same buffer at a flow rate of $1.0 \mathrm{ml} / \mathrm{min}$. The 75 fractions recovered were of $10 \mathrm{ml}$ each. The rich fractions of TGase activity obtained were pooled and called as purified enzyme.

\section{Analytical methods}

Determination of TGase activity. Transglutaminase activity was determined with colorimetric hydroxamate assay using N-carbobenzoxy-L-glutaminylglycine (Z-Gln-Gly) as a substrate according to Folk and Cole [1966].

$$
\underset{\text { CBZ-Gln-Gly + Hydroxylamine } \stackrel{\text { TGase }}{\longrightarrow}}{\longrightarrow}
$$

The enzyme solution $(0.5 \mathrm{ml})$ was added to $1 \mathrm{ml}$ of substrate solution. After an incubation with enzyme at $37^{\circ} \mathrm{C}$ for $10 \mathrm{~min}, 1.5 \mathrm{ml}$ of ferric chloridetrichloracetic acid reagent was added to the reaction mixture solution, To separate any insoluble material, the sample was centrifuged at $4500 \mathrm{rpm}$ for $10 \mathrm{~min}$. The supernatant was measured at $525 \mathrm{~nm}$ using an UV 1201-vis spectrophotometer SHIMDZU, Japan. The calibration was performed using L-Glutamic acid $\gamma$-monohydroxamate as standard. One unit of transglutaminase activity is defined as the amount of enzyme which catalyses the formation of $0.5 \mu$ mole of hydroxamate per min from Z-Gln-Gly and hydroxylamine at $\mathrm{pH} 6.0$ at $37^{\circ} \mathrm{C}$. Specific activity is expressed as enzyme units per $\mathrm{mg}$ protein.

Determination of protein content. Protein content was determined colorimetrically at $595 \mathrm{~nm}$ using Coomassie brilliant blue G-250 dye according to Bradford [1976]. The reaction mixture was composed of $10 \mu \mathrm{L}$ of enzyme extract, $490 \mu \mathrm{l}$ distilled water, and $500 \mu \mathrm{L}$ of Coomassie brilliant blue G-250 dye was added. The developed color was measured at $595 \mathrm{~nm}$, using a UV 1201-vis spectrophotometer SHIMDZU, Japan. Bovine serum albumin used as standard protein in range of $0.0-0.6 \mathrm{mg} / \mathrm{ml}$.

\section{Transglutaminase biochemical characteristics \\ Optimum pH. The enzyme activity was measured} at different $\mathrm{pH}$ values ranging from 3-9 using $0.2 \mathrm{M}$ citrate buffer ( $\mathrm{pH} 3$ ), $0.2 \mathrm{M}$ Acetate buffer ( $\mathrm{pH} 4-5)$, $0.2 \mathrm{M}$ phosphate buffer ( $\mathrm{pH} 6-7$ ), and $0.2 \mathrm{M}$ Tris- $\mathrm{HCl}$ buffer ( $\mathrm{pH} 8-9)$. The activity was measured after an incubation period of $10 \mathrm{~min}$ at each $\mathrm{pH}$.

Optimum temperature. Tubes containing the reaction mixture and enzyme extract were incubated at different temperatures ranging from 30 to $70^{\circ} \mathrm{C}$ for $10 \mathrm{~min}$. The enzyme activity was then assayed at each temperature to define the TGase optimal temperature.

Transglutaminase thermal stability. Aliquots of enzyme extract were heat treated for 5, 10, 15 and 20 min in water baths set at different temperatures of 50 to $85^{\circ} \mathrm{C}$ followed by rapid cooling to $37^{\circ} \mathrm{C}$ and analysed immediately for residual enzyme activity.

Effect of some salts and chelating agents on the enzyme activity. The presence of $10 \mathrm{mM}$ of $\mathrm{FeCl}_{3}$. $6 \mathrm{H}_{2} \mathrm{O}, \mathrm{MnSo}_{4} \cdot \mathrm{H}_{2} \mathrm{O}, \mathrm{ZnSo}_{4} \cdot 7 \mathrm{H}_{2} \mathrm{O}, \mathrm{CuSo}_{4} \cdot 5 \mathrm{H}_{2} \mathrm{O}, \mathrm{MgSo}_{4} \cdot$ $7 \mathrm{H}_{2} \mathrm{O}, \mathrm{BaCl}_{2} \cdot 2 \mathrm{H}_{2} \mathrm{O}$, EDTA and BME effect on enzyme activity was studied. The activity was measured under standard assay condition and the relative activity was calculated as the percentage of activity remaining after incubation with various reagents, the relative activity assayed in the absence of additives and without incubation was taken as $100 \%$. 
Effect of sodium chloride on the purified TGase activity. The presences of various concentrations of $\mathrm{NaCl}$ ranged from $2-14 \%$ effect on purified TGase activity were studied. The activity was measured under standard assay condition and the relative activity was calculated as the percentage of activity remaining after incubation with various concentrations of $\mathrm{NaCl}$, the relative activity assayed in the absence of additives and without incubation was taken as $100 \%$.

Effect of calcium chloride on the purified TGase activity. The presences of various concentrations of $\mathrm{CaCl}_{2}$ ranged from 2-14 $\mathrm{mM}$ effect on purified TGase activity were studied. The activity was measured under standard assay condition and the relative activity was calculated as the percentage of activity remaining after incubation with various concentrations of $\mathrm{CaCl}_{2}$, the relative activity assayed in the absence of additives and without incubation was taken as $100 \%$.

\section{RESULTS AND DISCUSSION}

\section{Purification of transglutaminase}

The purification and yield of transglutaminase from rosemary (Rosmarinus officinalis L.) is summarized in Table 1. Initially various purification methods [Clarke et al. 1959, Connellan et al. 1971, Brookhart et al. 1983] were tested in an attempt to increase the yield and minimize the loss of activity. The procedure adapted gave 347.0 specific activity as Z-Gln-Gly-Hydroxamate per mg protein with a yield of $21.35 \%$. During the precipitation step, ammonium sulfate salt was used to precipitate the enzyme proteins. The precipitate formed was immediately dissolved in $20 \mathrm{mM}$ Tris- $\mathrm{HCl}$ buffer, $\mathrm{pH} 7.4$ and dialyzed against the same buffer overnight. Under these conditions, (20-30\%) of ammonium sulfate saturation in the enzyme solution had a high yield of enzyme activity could be obtained. About $32.34 \%$ of the enzyme activity was precipitated with (20-30\%) ammonium sulfate with 1.68 fold increase in the specific activity. In the enzyme purification on DEAE-Sephadex A-50 chromatography column, TGase could be eluted between 0.2 and $0.3 \mathrm{M} \mathrm{NaCl}$ with a yield of $23.38 \%$, a specific activity of $168.8 \mathrm{U} / \mathrm{mg}$ protein and 3.56 fold purification (Fig. 3 and Table 1). Ion-exchange chromatography, such as DEAE-Sepharose, DEAE-cellulose, QSepharose, and SP-Sepharose, have been used to purify other TGase [Tokunaga and Iwanaga 1993, Ha and Iuchi 1997, Kumazawa et al. 1997]. The elution profile from DEAE-Sephadex A-50 chromatography of rosemary TGase was similar from other TGases such as human epidermal TGase was eluted at $0.2 \mathrm{M} \mathrm{NaCl}$ [Goldsmith and Martin 1995], and rat brain TGase was observed to be eluted at 0.28 $\mathrm{M}$ and $0.35 \mathrm{M}$ of $\mathrm{NaCl}$ concentration [Kwak et al. 1998]. The final step of purification was achieved

Table 1. Purification of transglutaminase from rosemary (Rosmarinus officinalis L.) leaves

\begin{tabular}{lcccccccc}
\hline \multicolumn{1}{c}{ Purification steps } & $\begin{array}{c}\text { Volume } \\
\mathrm{ml}\end{array}$ & $\begin{array}{c}\text { Activity* } \\
\text { unit/ml }\end{array}$ & $\begin{array}{c}\text { Protein } \\
\text { content* } \\
\mathrm{mg} / \mathrm{ml}\end{array}$ & $\begin{array}{c}\text { Total } \\
\text { activity } \\
\text { unit }\end{array}$ & $\begin{array}{c}\text { Total } \\
\text { protein } \\
\mathrm{mg}\end{array}$ & $\begin{array}{c}\text { Specific } \\
\text { activity } \\
\text { units/mg } \\
\text { protein }\end{array}$ & $\begin{array}{c}\text { Yield } \\
\%\end{array}$ & $\begin{array}{c}\text { Purification } \\
\text { fold }\end{array}$ \\
\hline Crude enzyme & 50 & 6.50 & 0.137 & 325.0 & 6.85 & 47.45 & 100 & 1.00 \\
$\begin{array}{l}\text { Ammonium sulfate } \\
\text { precipitation 20-30\% }\end{array}$ & 10 & 10.51 & 0.132 & 105.1 & 1.32 & 79.62 & 32.34 & 1.68 \\
$\begin{array}{l}\text { IEX on DEAE- } \\
\text {-Sephadex A-50 }\end{array}$ & 50 & 1.52 & 0.005 & 76.00 & 0.45 & 168.8 & 23.38 & 3.56 \\
$\begin{array}{l}\text { GFC on Sephadex } \\
\text { G-100 }\end{array}$ & 100 & 0.694 & 0.002 & 69.40 & 0.20 & 347.0 & 21.35 & 7.31 \\
\hline
\end{tabular}

$*$ Based on 50 g rosemary. Specific activity $=$ enzyme activity/protein content, total activity $=$ enzyme activity $\times$ fraction volume, yield $=$ total activity of purified enzyme/total activity of crude enzyme $\times 100$, fold of purification $=$ specific activity of purified enzyme/specific activity of crude enzyme. IEX - ion exchange chromatography, GFC - gel filtration chromatography. 


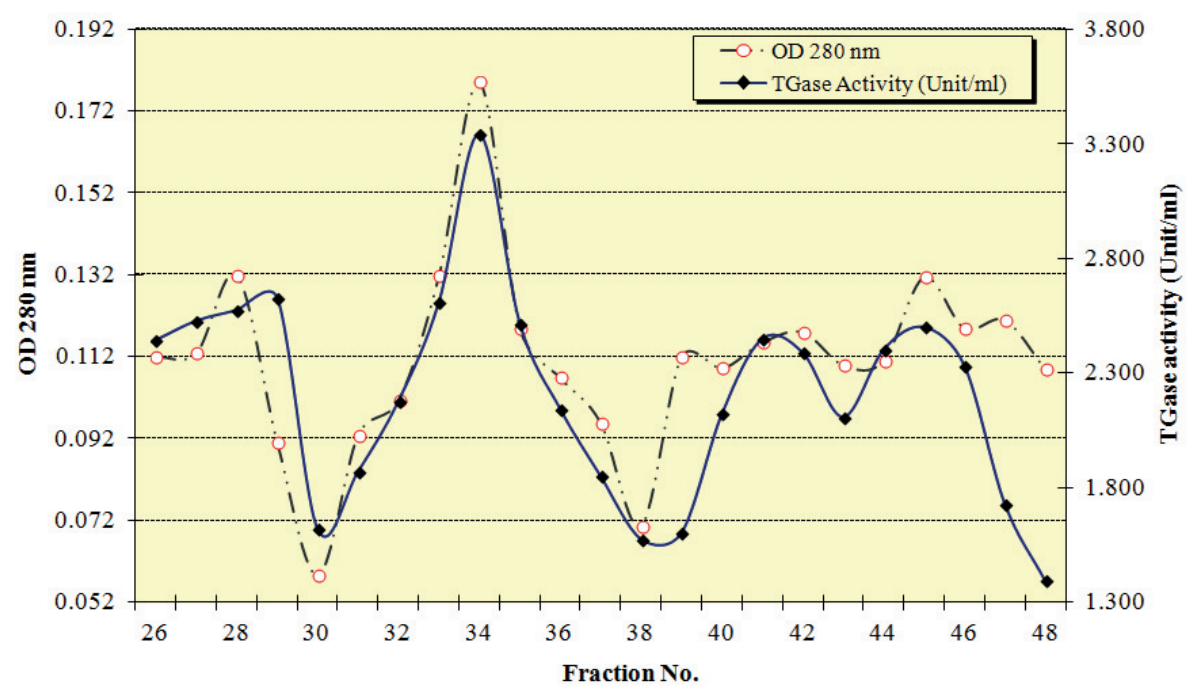

Fig. 3. Chromatogram of rosemary (Rosmarinus officinalis L.) TGase by IEX on DEAE-Sephadex A-50: IEX - ion exchange chromatography

by subjecting the pooled enzyme fraction from the previous step to purify on Sephadex G-100 column (Fig. 4), TGase activity was eluted as a single peak at fraction 7 to 16 which resulted in 7.31 fold purification with a yield of $21.35 \%$ and a specific activity of
$347.0 \mathrm{U} \cdot \mathrm{mg}^{-1}$ protein as compared to the crude extract (Table 1), the final recovery yield of the purified rosemary TGase was similar to that guinea pig liver TGase [Folk 1970, Tokunaga and Iwanaga 1993]. Sephadex G-100 chromatography column was used to

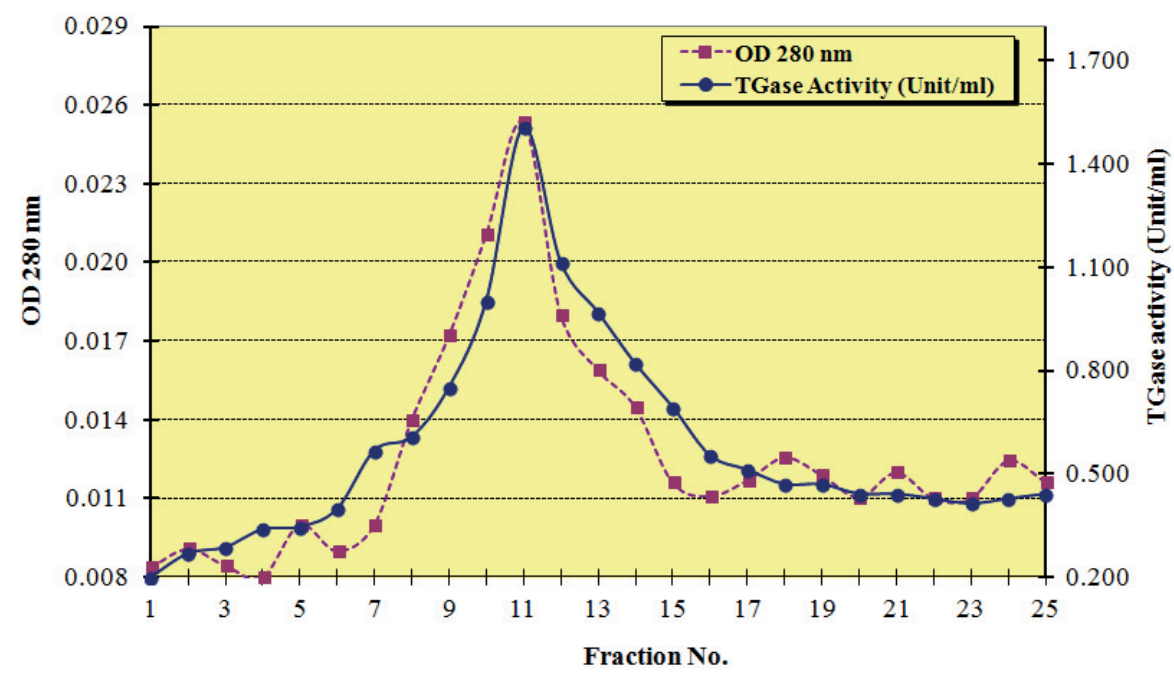

Fig. 4. Chromatogram of rosemary (Rosmarinus officinalis L.) TGase by GFC on Sephadex G-100: GFC - gel filtration chromatography 
purify TGase from rat liver with $5.0 \%$ yield thus it is lower than our study [Wong et al. 1990].

\section{Effect of pH on enzyme activity}

The effect of $\mathrm{pH}$ on TGase activity was determined using the reaction mixtures as described previously at $\mathrm{pH} 3.0-9.0$ at $37^{\circ} \mathrm{C}$. The enzyme exhibited optimum activity for the catalytic reaction of Z-Gln-Gly and hydroxylamine at $\mathrm{pH}$ 7.0. The rosemary TGase activity was declined sharply at alkaline $\mathrm{pH}$, but it increased gradually at acidic $\mathrm{pH}$ (Fig. 5). The optimum $\mathrm{pH}$ of rosemary TGase was nearly the same as that of plant TGase from soybean (Glycine max) [Kang and Cho 1996]; animal TGase from tropical tilapia [Worratao and Yongsawatdigul 2005]; microbial TGase from Streptoverticillium [Ando et al. 1989, Gerber et al. 1994, Cui et al. 2007]. It was different from other mammals TGase that had an optimum $\mathrm{pH}$ value of 9.0 [Wong et al. 1990]; plant TGase from (dicotyledonous) Pea and bean TGase (monocotyledonous) wheat and barley had an optimal pH value of 7.9 [Lilley et al. 1998]; microbial TGase from Bacillus subtilis that has an optimal $\mathrm{pH}$

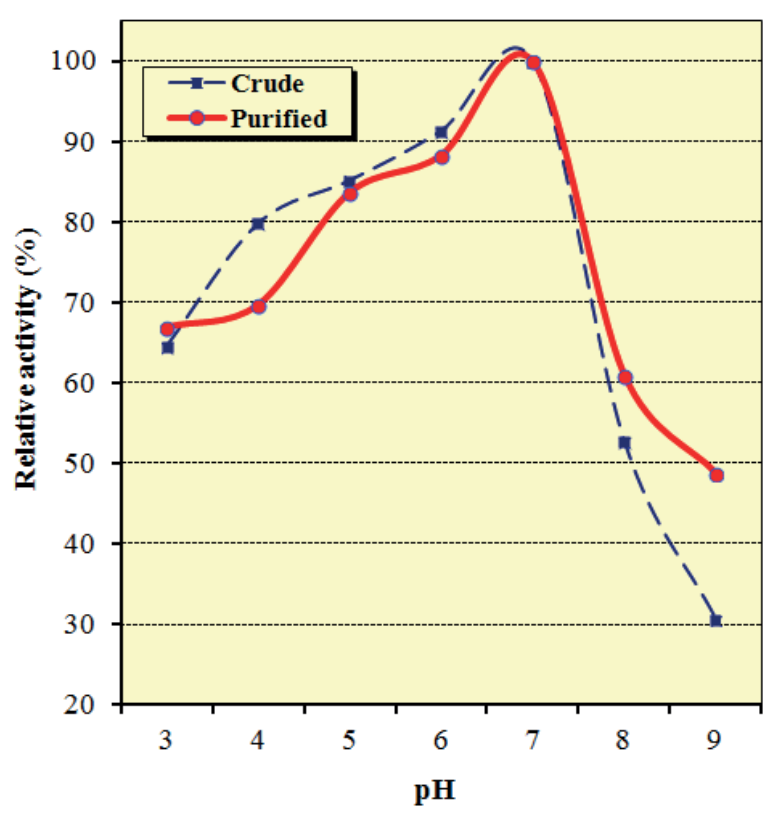

Fig. 5. Effect of $\mathrm{pH}$ on the TGase activity from rosemary (Rosmarinus officinalis L.) leaves value of 8.2 [Suzuki et al. 2000]. It should be noted that Rosemary TGase has a broader $\mathrm{pH}$ range than TGases from other sources.

\section{Effect of temperature on enzyme activity}

The temperature effects on TGase activity were studied by determining the activity between 30 to $70^{\circ} \mathrm{C}$ after incubation for $10 \mathrm{~min}$ at $\mathrm{pH}$ 6.0, with the reaction mixtures as indicated previously. The enzyme exhibited optimum activity at $55^{\circ} \mathrm{C}$ for the catalytic reaction of Z-Gln-Gly and hydroxylamine (Fig. 6). The optimal temperature of the purified TGase varied with sources, comparing with other TGases from different sources, the optimal temperature of rosemary TGase almost was the same as that from Streptoverticillium mobaraense TGase [Lu et al. 2003], and it was nearly similar to that of Streptoverticillium ladakanu and Bacillus subtilis TGase, which had optimal temperature of $60^{\circ} \mathrm{C}$ [Ho et al. 2000, Suzuki et al. 2000]. While it was completely diverging from soybean (Glycine max) and Streptoverticillium hygroscopicus exhibited the optimal activity at $37^{\circ} \mathrm{C}$ and $37-45^{\circ} \mathrm{C}$, respectively [Kang and Cho 1996, Cui et al. 2007].

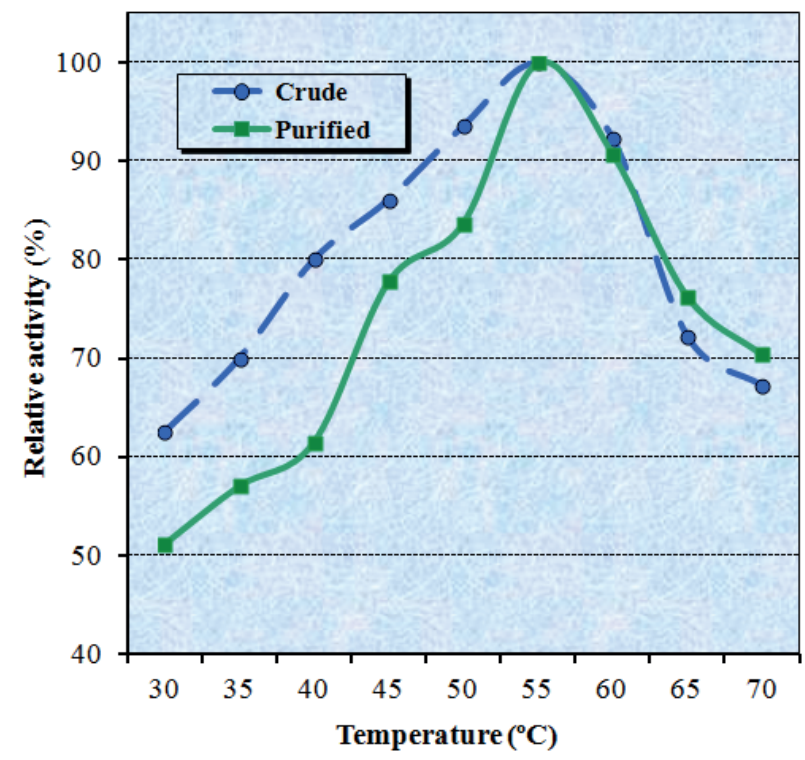

Fig. 6. Temperature profile of the TGase activity from rosemary (Rosmarinus officinalis L.) leaves 


\section{Thermal stability of the purified TGase}

The thermal stability of the purified TGase was investigated between 50 and $85^{\circ} \mathrm{C}$. Rosemary TGase lost its activity with incubation period and temperature increased. It almost maintained full activity after incubation for 15 min up to $60^{\circ} \mathrm{C}$ and retained about $80 \%$ of the initial activity after incubation for the same period up to $65^{\circ} \mathrm{C}$. When the temperature was above $70^{\circ} \mathrm{C}$, it was declined rapidly inactivated and it was completely inactivated at $85^{\circ} \mathrm{C}$ (Fig. 7). The purified TGase from rosemary was thermal stable compared with rat liver TGase where it was quite sensitive to temperature of incubation and complete inactivation was observed after heating for $4 \mathrm{~min}$ at $52^{\circ} \mathrm{C}$, and after $1 \mathrm{~min}$ at $60^{\circ} \mathrm{C}$ [Wong et al. 1990].

\section{Effect of different metal ions and other materials on enzyme activity}

The relative activity of TGase was investigated in the presence of several metal ions and other materials: EDTA and BME which were added at $10 \mathrm{mM}$ concentration to enzyme preparations and left for 30 min at $37^{\circ} \mathrm{C}$ (Fig. 8). Rosemary TGase was moderately inhibited by $\mathrm{Fe}^{+2}, \mathrm{Cu}^{+2}$ and $\mathrm{Mn}^{+2}$ while it was not

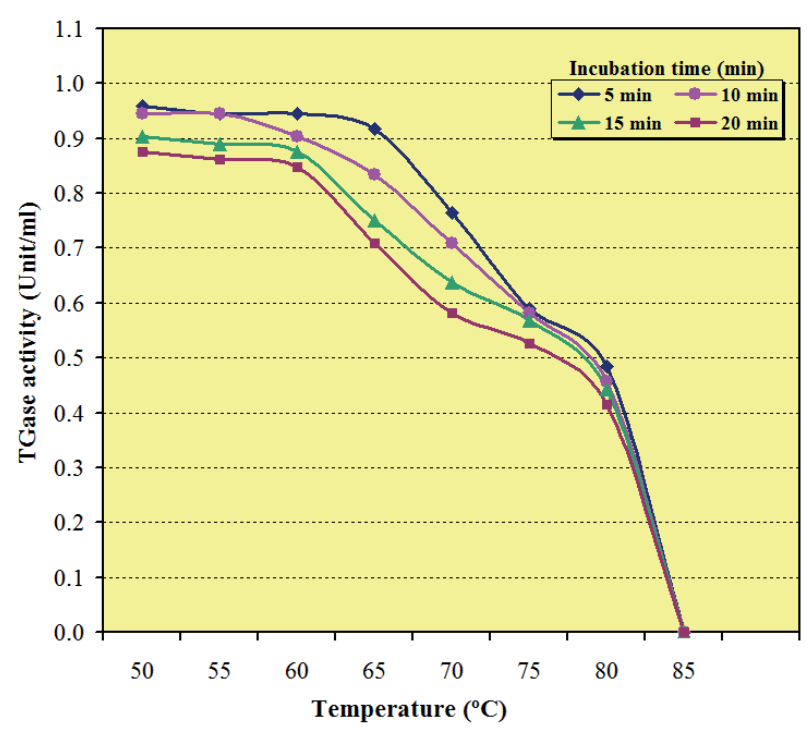

Fig. 7. Thermal stability of the purified TGase from rosemary (Rosmarinus officinalis L.) leaves

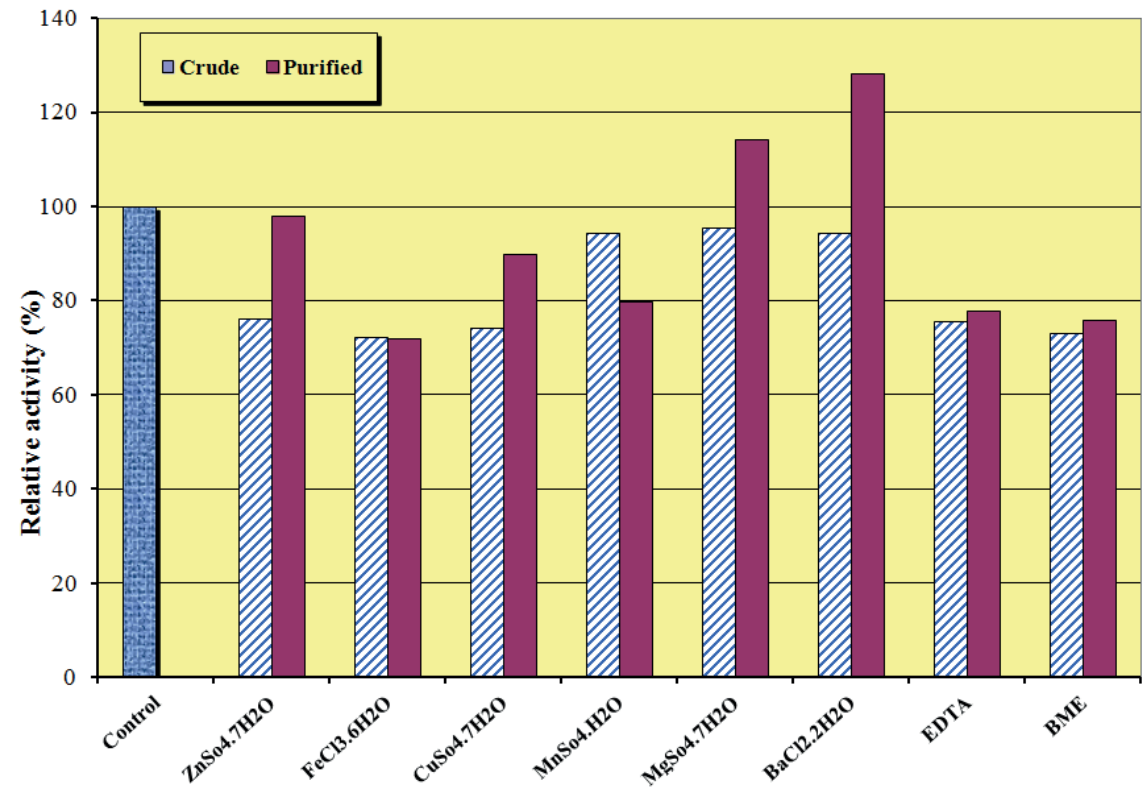

Fig. 8. Influence of various materials on the TGase from rosemary (Rosmarinus officinalis L.) leaves: EDTA - Ethylenediaminetetraacetic acid, BME - $\beta$-mercaptoethanol 
inhibited by $\mathrm{Mg}^{+2}, \mathrm{Ba}^{+2}$ and $\mathrm{Zn}^{+2}$. The rosemary TGase was not inhibited by $\mathrm{Mg}^{2+}$, and $\mathrm{Ba}^{2+}$ was similar to those from microbial sources [Ando et al. 1989, Ho et al. 2000, Barros et al. 2003, Cui et al. 2007]. Inactivation of the enzyme by $\mathrm{Cu}^{+2}$ may have been caused by the metal-catalysed oxidation of the cysteine, and the inactivated enzyme was shown to contain two new disulfide bonds [Boothe and Folk 1969]. The rosemary TGase shows slight activation by $\mathrm{Mg}^{+2}$ in agreement with the TGase isolated from particulate fractions of rat chondrosarcoma cells [Chang and Chung 1986]. Chelating agents, like EDTA caused a moderate inhibition of the purified TGase and BME moderately inhibited TGase activity.

\section{Effect of calcium chloride $\left(\mathrm{CaCl}_{2}\right)$ on the purified TGase}

The relative activity of TGase was investigated in the presence of various concentration of $\mathrm{CaCl}_{2}$ which were incubated with enzyme preparations and left for $30 \mathrm{~min}$ at $37^{\circ} \mathrm{C}$. The TGase activity displayed by rosemary leaves extract shows stimulation by $\mathrm{Ca}^{+2}$ when measured with Z-Gln-Gly as substrate and the maximum activity at $2 \mathrm{mM}$ (Fig. 9), but about $5-20 \%$ was lost from its activity by increasing $\mathrm{CaCl}_{2}$ concentration. The optimal $\mathrm{CaCl}_{2}$ concentration is similar with

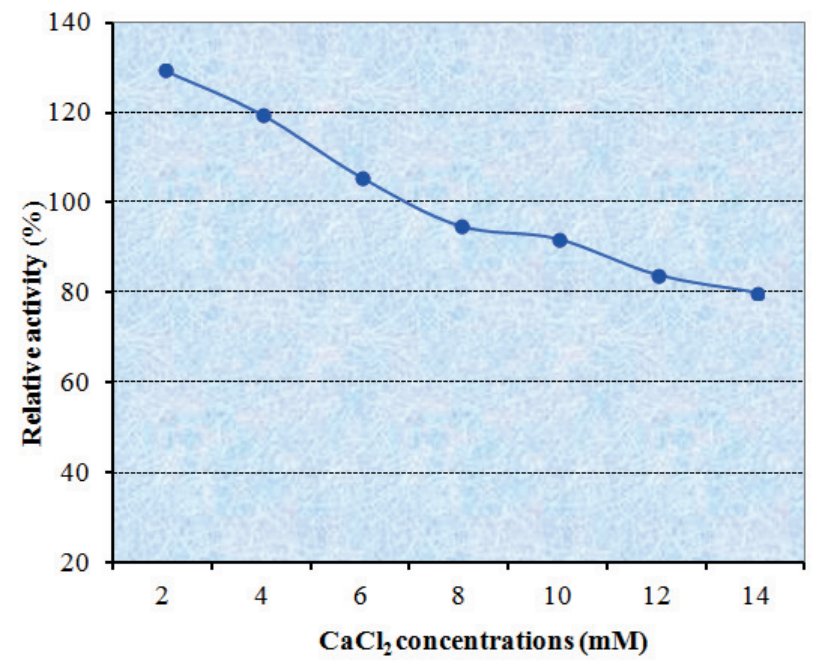

Fig. 9. Effect of calcium chloride $\left(\mathrm{CaCl}_{2}\right)$ concentrations on the purified TGase from rosemary (Rosmarinus officinalis L.) leaves the TGase isolated from Helianthus tuberosus leaves, pollock liver, and tropical tilapia, it was at 1-3 mM, $3 \mathrm{mM}$, and $1.25 \mathrm{mM}$, respectively [Del Duca et al. 1994, Yasueda et al. 1994, Worratao and Yongsawatdigul 2005] while horseshoe crab TGase was required $10 \mathrm{mM}$ of $\mathrm{Ca}^{+2}$ for maximum activity [Tokunaga and Iwanaga 1993]. It was also reported that the activity of the TGase from Streptoverticillum sp. strain s-8112, Soybean (Glycine max) leaves was not dependent on $\mathrm{Ca}^{+2}$ [Kanaji et al. 1993, Kang and Cho 1996]. It was postulated that the calcium ion induced the conformational changes of the enzyme, which consequently exposed the cysteine located at the active site to a substrate [Jiang and Lee 1992]. Noguchi et al. [2001] reported that the calcium ion bound to a binding site of red sea bream TGase molecule, resulting in conformational changes. Subsequently, Tyr covering the catalytic Cys was removed. Then, the acyl donor bind with the Cys at the active site, forming an acyl-enzyme intermediate. The rosemary TGase was not inhibited by $\mathrm{Ca}^{2+}$ and EDTA, suggesting it was calcium-independent, which was completely different from those of calcium-dependent TGases from animal tissues or organs [Worratao and Yongsawatdigul 2005] and was similar to those from microbial sources [Ando et al. 1989, Barros et al. 2003, Ho et al. 2000, Cui et al. 2007]. This property is very useful in modifying food proteins, as many food proteins such as milk caseins, soybean and myosin are sensitive and easily precipitated by $\mathrm{Ca}^{2+}$ [Yokoyama et al. 2004].

\section{Effect of sodium chloride ( $\mathrm{NaCl}$ ) on the purified TGase}

The relative activity of TGase was studied in the presence of various concentration of $\mathrm{NaCl}$ which were incubated with enzyme preparations and left for 30 min at $37^{\circ} \mathrm{C}$ (Fig. 10). The rosemary TGase activity shows no noticeable inhibition by $\mathrm{NaCl}$ in the range of $2-14 \%$. This result was agreement with the tropical tilapia TGase [Worratao and Yongsawatdigul 2005], and the horseshoe crab TGase [Tokunaga and Iwanaga 1993] where it be noted that the TGase activity inhibited by $\mathrm{NaCl}$ concentrations above $0.5 \mathrm{M}$. High concentration of $\mathrm{NaCl}$ could induce conformational changes in the enzyme molecule, resulting in a decrease of TGase activity [Kishi et al. 1991, Kumazawa et al. 1997]. 




Fig. 10. Effect of sodium chloride $(\mathrm{NaCl})$ concentrations on the purified TGase from rosemary (Rosmarinus officinalis L.) leaves

\section{CONCLUSIONS}

This paper reports on the purification and characterization of transglutaminase from newly isolated plant, rosemary (Rosmarinus officinalis L.). The purified TGase was gained after three successive purification steps. Rosemary TGase had the highest acivity, enzyme yield, specific activity and easy separation and purification compared to other plants in the preliminary studies. The enzyme exhibited optimum activity in a range of $\mathrm{pH} 5.0-7.0$ and at $50-60^{\circ} \mathrm{C}$ for the catalytic reaction of hydroxylamine and Z-Gln-Gly. The purified TGase was calcium-independent and in this respect is quite different from animal tissue TGase. The rosemary TGase activity shows no noticeable inhibition by $\mathrm{NaCl}$ in the range of $2-14 \%$. These properties make this enzyme a good candidate for application in the food industry. However, additional work is required to increase activity yield during extraction and purification for commercial scale of TGase from this plant.

\section{REFERENCES}

Aeschlimann D., Paulsson M., 1994. Transglutaminase: Protein cross-linking enzymes in tissues and body fluids. Thromb. Haemostasis 71, 402-415.
Ando H., Adachi M., Umeda K., Matsuura A., Nonaka M., Uchio R., 1989. Purification and characterization of a novel Transglutaminase derived from micro-organisms. Agric. Biol. Chem. 53, 2613-2617.

Barros S.L.H., Assmann F., Zachia A.M.A., 2003. Purification and properties of a transglutaminase produced by a Bacillus circulans strain isolated from the Amazon environment. Biotechnol. Appl. Biochem. 37, 295-299.

Boothe R.L., Folk J.E., 1969. A reversible, calcium-dependent. copper-catalyzed inactivation of guinea pig liver transglutaminase. J. Biol. Chem. 244, 399-405.

Bradford M.M., 1976. A rapid and sensitive method for the quantitation of microgram quantities of protein utilizing the principle of protein-dye binding. Ann. Biochem. 72, 248-254.

Brookhart P.P., McMahon P.L., Takahashin M., 1983. Purification of guinea pig liver transglutaminase using a phenylalanine-Sepbarose 4B affinity column. Anal. Biochem. 128, 202-205.

Chang S.K., Chung S.L., 1986. Cellular transglutaminase. The particular-associated transglutaminase from chrondrosarcoma and liver: partial purification and characterization. J. Biol. Chem. 261, 8112-8121.

Clarke D.D., Mycek M.J., Neidle A., Wacllsch H., 1959. The incorporation of amines into protein. Arch. Biochem. Biophys. 79, 338-354.

Colowick S.P., Kaplan N., 1955. Methods in enzymology. Vol. 1. Academic Press New York.

Connellan J.M., Chune S.I., Whetzel N.K., Bradlev L.M., Folk J.E., 1971. Structural properties of guinea pig liver transglutaminase. J. Biol. Chem. 246, 1093-1098.

Cortez J., Bonner P.L.R., Griffin M., 2004. Application of transglutaminases in the modification of wool textiles. Enzyme Microb. Tech. 34, 64-72.

Cui L., Du G., Zhang D., Liu H., Chen J., 2007. Purification and characterization of transglutaminase from a newly isolated Streptomyces hygroscopicus. Food Chem. 105, 612-618.

Del Duca S., Tidu V., Bassi R., Esposito C., Serafini-Fracassini D., 1994. Identification of chlorophyll-a/b proteins as substrates of transglutaminase activity in isolated chloroplasts of Helianthus tuberosus L. Planta 193, 283-289.

Fernández-López J., Zhi N., Aleson-Carbonell L., Pérez-Alvarez J.A., Kuri V., 2005. Antioxidant and antibacterial activities of natural extracts: application in beef meatballs. Meat Sci. 69, 371-380.

Folk J.E., Cole P.W., 1966. Identification of a functional cysteine essential for the activity of guinea pig liver transglutaminase. J. Biol. Chem. 241, 3238-3240. 
El-Hofi M., Ismail A., Nour M., Ibrahim O., 2014. Isolation, purification and characterisation of transglutaminase from rosemary (Rosmarinus officinalis L.) leaves. Acta Sci. Pol., Technol. Aliment. 13(3), 267-278.

Folk J.E., 1970. Transglutaminase (Guinea Pig Liver). Methods Enzym. 17, 889-894.

Folk J.E., 1980. Transglutaminases. Annual Rev. Biochem. 49, 517-531.

Genena A.K., Hense H., Smânia Junior A., Machado de Souza S., 2008. Rosemary (Rosmarinus officinalis) - a study of the composition, antioxidant and antimicrobial activities of extracts obtained with supercritical carbon dioxide. Ciênc. Tecnol. Aliment. 28 (2), 463-469.

Gerber U., Jucknischke U., Putzien S., Fuchsbauer H.L., 1994. A rapid and simple method for the purification of transglutaminase from Streptoverticillium mobaraense. Biochem. J. 299, 825-829.

Goldsmith L.A., Martin G.M., 1995. Human epidermal transglutaminase. J. Invest. Dermatol. 64, 316-321.

Gomori G., 1955. Preparation of buffers for use in enzyme studies. Method. Enzymol. 1, 138-146.

Ha C.R., Iuchi I., 1997. Purification and partial characterization of $76 \mathrm{kDa}$ transglutaminase in the egg envelope (chorion) of rainbow trout, Oncorhynchus mykiss. Biochem. J. 122, 947-954.

Ho M.L., Leu S.Z., Hsieh J.F., Jiang S.T., 2000. Technical approach to simplify the purification method and characterization of microbial transglutaminase produced from Streptoverticilliun ladakanu. J. Food Sci. 65, 76-80.

http://www.bioeng.cstm.kyushu-u.ac.jp/enzyme/Transglutamiase 1.html.

Icekson I., Apelbaum A., 1987. Evidence for transglutaminase activity in plant tissue. Plant Physiol. 84, 972-974.

Jiang S.T., Lee J.J., 1992. Purification, and characterization of pig plasma factor XIIIa. J. Agric. Food Chem. 40, 1101-1107.

Josten A., Meusel M., Spencer F., Haalk L., 1999. Enzyme immobilization via microbial transglutaminase: A method for the generation of stable sensing surface. J. Mol. Cat. B: Enzymatic 7, 58-66.

Kanaji T., Ozaki H., Takao T., Kawajiri H., Ide H., Motoki M., Shimonishi Y., 1993. Primary structure of microbial transglutaminase from Streptoverticillium sp. strain s-8112. J. Biol. Chem. 268, 11565-11572.

Kang H., Cho Y.D., 1996. Purification and properties of transglutaminase from soybean (Glycine max) leaves. Biochem. Biophys. Res. Commun. 223, 288-292.

Kishi H., Nozawa H., Seki N., 1991. Reactivity of muscle transglutaminase on carp myofibrils and myosin B. Nippon Suisan Gakk. 57, 1203-1210.

Kumazawa Y., Sano K., Seguro K., Yasueda H., Nio N., Motoki M., 1997. Purification and characterization of transglutaminase from Japanese oyster (Crassostrea gigas). J. Agric. Food Chem. 45, 604-610.
Kwak S.J., Kim S.Y., Kim Y.S., Song K.Y., Kim I.G., Park S.C., 1998. Isolation and characterization of brain-specific transglutaminases from rat. Exp. Mol. Med. 30, 177-185.

Leal P.F., Braga M.E., Sato D.N., Carvalho J.E., Marques M.O., Meireles M.A., 2003. Functional properties of spice extracts obtained via supercritical fluid extraction. J. Agric. Food Chem. Campinas 51 (9), 2520-2525.

Li-Chan E.C.Y., 2004. Properties of proteins in food systems: an introduction. In: Proteins in food processing. Ed. R.Y. Yada. CRC Press Boca Raton, FL, 2-26.

Lilley G.R., Skill J., Griffin M., Philip L.R., 1998. Detection of $\mathrm{Ca}^{+2}$-dependent transglutaminase activity in root and leaf tissue of monocotyledonous and dicotyledonous plants. Plant Physiol. 117, 1115-1123.

Lin S., Hsieh Y., Wang P., Chu W., 2007. Efficient purification of transglutaminase from recombinant Streptomyces platensis at various scales. Biotechnol. Lett. 29, 111-115.

Lu S.Y., Zhou N.D., Tian Y.P., Chen J., 2003. Purification and properties of transglutaminase from Streptoverticillium mobaraense. J. Food Biochem. 27, 109-126.

Mirzaei M., 2011. Microbial transglutaminase application in food industry. Int. Conferen. Food Eng. Biotechn. 9, 267-271.

Noguchi K., Ishikawa K., Yokoyama K.I., Ohtsuka T., Nio N., Suzuki E.I., 2001. Crystal structure of red sea bream transglutaminase. J. Biol. Chem. 276, 12055-12059.

Oluwatuyi M., Kaatz G.W., Gibbons S., 2004. Antibacterial and resistance modifying activity of Rosmarinus officinalis L. Phytochemistry 65 (24), 3249-3254.

Signorini M., Beninati S., Bergamini D., 1991. Identification of transglutaminase activity in the leaves of silver beet (Beta vulgaris L.). J. Plant Physiol. 137, 547-552.

Suzuki S., Izawa Y., Kobayashi K., Eto Y., Yamanaka S., Kubota K., 2000. Purification and characterization of novel transglutaminase from Bacillus subtilis spores. Biosci. Biotechn. Biochem. 64, 2344-2351.

Tawaha K., Feras A.Q., Mohammad G., Mohammad M., Tamam E., 2007. Antioxidant activity and total phenolic content of selected Jordanian plant species. Food Chem. 104 (4), 1372-1378.

Tokunaga F., Iwanaga S., 1993. Horseshoe crab transglutaminase. Meth. Enzymol. 223, 378-388.

Villalobos E., Torné J.M., Rigau J., Ollés I., Claparols I., Santos M., 2001. Immunogold localization of a transglutaminase related to grana development in different maize cell types. Protoplasma 216, 155-163.

Wilhelm B., Meinhardt A., Seitz J., 1996. Transglutaminases: purification and activity assays. J. Chromatogr. 684, 163-177. 
Wong W.S.D., Batt C., Kinsella J.E., 1990. Purification and characterization of rat liver transglutaminase. Int. J. Biochem. 22 (1), 53-59.

Worratao A., Yongsawatdigul J., 2005. Purification and characterization of transglutaminase from tropical tilapia (Oreochromis niloticus). Food Chem. 93, 651-658.

Yasueda H., Kumazawa Y., Motoki M., 1994. Purification and characterization of a tissue-type transglutaminase from red sea bream (Pagrus major). Biosci. Biotechn. Biochem. 58, 2041-2045.
Yokoyama K., Nio N., Kikuchi Y., 2004. Properties and applications of microbial transglutaminase. Appl. Microbiol. Biotechnol. 64, 447-454.

Zhu Y., Rinzema A., Tramper J., Bol J., 1995. Microbial transglutaminase - a review of its production and application in food processing. Appl. Microbiol. Biotechnol. 44, 277-282.

Accepted for print - Zaakceptowano do druku: 18.03.2014

Received - Przyjęto: 19.01.2014

For citation - Do cytowania

El-Hofi M., Ismail A., Nour M., Ibrahim O., 2014. Isolation, purification and characterisation of transglutaminase from rosemary (Rosmarinus officinalis L.) leaves. Acta Sci. Pol., Technol. Aliment. 13(3), 267-278. 